\title{
Loss of the p53 Tumor Suppressor Gene Protects Neurons from Kainate-Induced Cell Death
}

\author{
Richard S. Morrison, ${ }^{1}$ H. Jurgen Wenzel, ${ }^{1}$ Yoshito Kinoshita, ${ }^{1}$ Carol A. Robbins, ${ }^{1}{ }^{2}$ arry A. Donehower, ${ }^{2}$ and \\ Philip A. Schwartzkroin 1
}

${ }^{1}$ Department of Neurological Surgery, University of Washington School of Medicine, Seattle, Washington 98195-6470, and 2Division of Molecular Virology, Baylor College of Medicine, Houston, Texas 77030

The tumor suppressor gene p53 recently has been associated with the induction of cell death in response to some forms of cellular damage. A possible role for p53-related modulation of neuronal viability has been suggested by the finding that p53 expression is increased in damaged neurons in models of ischemia and epilepsy. We evaluated the possibility that p53 expression (in knockout mice) is required for induction of cell damage in a model of seizure activity normally associated with well defined patterns of cell loss. Subcutaneous injection of kainic acid, a potent excitotoxin, induced comparable seizures in both wild-type mice $(+/+)$ and mice deficient in p53 (-/-). Using a silver impregnation technique to examine neurodegeneration in animals killed $7 \mathrm{~d}$ after kainate injection, we found that a majority of $+/+$ mice exhibited extensive cell loss in the hippocampus, involving subregions CA1, CA3, the hilus, and the subiculum. Apoptotic cell death, as identified with an in situ nick end labeling technique to detect DNA fragmentation, was confirmed in CA1- but not CA3-degenerating neurons. In marked contrast, a majority of p53 - /- mice displayed no signs of cell damage; in the remaining p53 - /- mice, damage was mild to moderate and was confined almost entirely to cells in CA3b of the dorsal hippocampus. In $+/+$ mice, but not in $-/-$ mice, damaged neurons also were observed in the amygdala, piriform cortex, cerebral cortex, caudate-putamen, and thalamus after kainate treatment. The pattern and extent of damage in mice heterozygous for p53 $(+/-)$ were identical to those seen in $+/+$ mice, suggesting that a single copy of p53 is sufficient to confer neuronal vulnerability. These results demonstrate that $\mathrm{p} 53$ influences viability in multiple neuronal subtypes and brain regions after excitotoxic insult.

Key words: p53; neurons; brain injury; epilepsy; apoptosis; hippocampus; excitotoxin
The p53 tumor suppressor gene encodes a nuclear phosphoprotein that functions as a key regulator of cellular proliferation. p53 also is recognized as belonging to a pathway responsible for DNA damage repair, which is critical for maintaining genomic stability. Loss or inactivation of the p53 tumor suppressor gene occurs in almost half of all human tumors (Greenblatt et al., 1994) and is considered a fundamental, predisposing event in the pathogenesis of many cancers. Patients carrying germline mutations in p53 are at higher risk for developing a variety of tumors (Malkin et al., 1990; Srivastava et al., 1990), and mice deficient in p53 display precocious tumor development (Donehower et al., 1992; Harvey et al., 1993; Jacks et al., 1994; Purdie et al., 1994).

p53 may also influence tumor development by regulating the extent of cell death or apoptosis. Expression of wild-type p53 has been shown to induce spontaneous cell death in some cultured cell lines (Yonish-Rouach et al., 1991; Shaw et al., 1992) while rendering other cells more sensitive to induction of apoptosis (Lowe et al., 1993; Bristow et al., 1994; Fisher, 1994). These observations have been extended to tumors grown in vivo. In transgenic mice, p53 recently has been shown to suppress tumor

Received Sept. 6, 1995; revised Nov. 8, 1995; accepted Nov. 10, 1995.

This work was supported in part by Grants NS31775 (R.S.M.) and NS15317 (P.A.S.) from National Institutes of Health. We gratefully ackilowledye Dr. Catherine Woolley for assisting with the assessment of neuronal damage, James Owens for his help with the statistical analysis, and Chizuru Kinoshita for her technical expertise. We also acknowledgc Dr. Harley Kornblum for critically reading this manuscript and Erin Cromett for helping to prepare this manuscript.

Correspondence should be addressed to Dr. Richard Morrison, Department of

Neurological Surgery, University of Washington School of Medicine, Box 356470,

Seattle, WA 98195-6470.

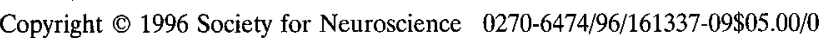

growth by promoting apoptosis of abnormally proliferating tumor cells (Symonds et al., 1994).

The demonstration that $\mathrm{p} 53$ promotes apoptosis in abnormally proliferating cells may have important implications for the CNS, where cell death is observed normally during development, in response to injury, and in neurodegenerative disorders such as Alzheimer's and Huntington's diseases (Appel, 1981; Raff et al., 1993). Indeed, p53 induction recently has been associated with neuronal damage in the CNS (Sakhi et al., 1994). In these studies, systemic injection of kainic acid (KA), a potent excitotoxin that produces seizures associated with a defined pattern of neuronal cell loss, induced p53 expression in neurons exhibiting morphological evidence of damage; pretreatment with a protein synthesis inhibitor prevented both KA-induced p53 expression and neuronal damage. These results suggest the exciting possibility that p53 induction may promote irreversible injury in postmitotic cells of the CNS via a pathway of programmed cell death.

The development of mice deficient in both p53 alleles (Donehower et al., 1992) has provided a model for assessing the role of p53 in nervous system injury. In the present study, we evaluated the role of p53 in regulating neuronal viability using a well defined model of neuronal toxicity. The model involves the application of $\mathrm{KA}$, a potent excitotoxin, that utilizes the AMPA $/$ kainate class of glutamate receptor (London and Coyle, 1979). Administration of kainate to rodents induces a period of generalized seizure activity (occurring over the course of several hours) that is followed by well defined patterns of neuronal degeneration in the hippocampus and other brain regions (Nadler et al., 1978; Repressa et al., 1987). We found that the absence of p53 ( $-/-$ mice) caused 
almost complete protection from kainate-induced injury. These results suggest that $\mathrm{p} 53$ induction may play a direct role in promoting neuronal degeneration in response to some forms of brain injury and disease.

\section{MATERIALS AND METHODS}

p53-deficient mice. Mice deficient in the 533 tumor suppressor gene were generated from a $129 / \mathrm{Sv} \times \mathrm{C} 57 \mathrm{BL} / 6$ background as described previously (Donehower et al., 1992). To ensure the genotype of the offspring, matings generally were performed between two wild-type $(\mathrm{p} 53+/+)$ mice (for p53 $+1+$ offspring), one p53 $+/+$ and one p53 $-1-$ mouse [for heterozygous (p53 $+1-$ ) offspring], or two p53 -1- mice (for p53-1offspring). The genotypes of the mating pairs were confirmed as described previously using PCR and DNA extracted from mouse tails (Timme and Thompson, 1994). In the few cases in which $-/-$ mice were obtained from matings involving one $+/-$ mouse and one $-/-$ mouse, the offspring were genotyped three separate times to ensure the correct assignment.

Behavioral assessment of seizure threshold. KA (K-0250, monohydrate, Sigma, St. Louis, MO) was administered subcutaneously to 8- to 10 -weekold mice at $35 \mathrm{mg} / \mathrm{kg}$ body weight (a dose we established in preliminary studies as appropriate for producing significant lesions in wild-typc animals, with mortality of $\leq 25 \%$ ). Doses in excess of $35 \mathrm{mg} / \mathrm{kg}$ body weight proved to be lethal. Seizure onset occurred within $30 \mathrm{~min}$ and persisted for 2-3 hr. Animals were observed during the seizure period to determine the duration and severity of seizure activity. In all of the assessments, the experimenter was blind to the genotype of the animal.

Behavioral observations during the first $2 \mathrm{hr}$ after kainate injection revealed a progression of increasingly severe seizure-related behaviors. These behaviors were scored on a scale from 0 to 7 with 0 representing normal behavior and 7 representing death. The combined mortality rate for animals of all genotypes was $25 \%(15 / 61)$. Within a few minutes after kainate injection, typical activity such as walking, exploring, sniffing, and grooming ceased and the mice became motionless. This immobility (stage 1) frequently was followed by a period of forelimb and/or tail extension, giving the appcarance of a rigid posture (stage 2). Automatisms such as repetitive scratching, circling, or head bobbing (stage 3 ) were followed in most animals by seizure behaviors comprised of forelimb clonus and rearing and falling (stage 4 ). This pattern sometimes was repeated over and over (stage 5). A small percentage (13\%) of surviving mice experienced more severe, tonic-clonic, seizures (stage 6).

Seizure rating was obtained as follows. The highest stage of seizurerelated activity was noted for each 5 min period for $2 \mathrm{hr}$ after injection. Each seizure behavior score ( $0-6)$ was multiplied by the number of $5 \mathrm{~min}$ periods in which the animal received that score. These numbers were added together for a raw score, and the final seizure ratings were derived from these raw scores. Raw scores less than 50 were assigned a rating of 1 , those between 50 and 79 received a rating of 2 , and those 80 and above received a rating of 3 . Animals exhibiting no seizure activity received a rating of 0 .

Morphological description of neuronal damage. Animals were analyzed histologically at $1,2,4,7,10$, and $12 \mathrm{~d}$ after kainate treatment, although data are presented only for the day 7 time point. Mice were anesthetized dceply (pentobarbital, $45 \mathrm{mg} / \mathrm{kg}$, i.p.) and perfused transcardially $(4 \%$ $p$-formaldehyde), and the brains were removed and processed for Nissl staining and silver impregnation for cell degeneration. For histological procedures, $30-\mu \mathrm{m}$-thick frozen sections were cut through the hippocampus; representative sections from dorsal and ventral regions of hippocampus were obtained from each animal, with comparable levels of section analyzed for all three genotypes.

To estimate the degree of kainate-induced damage, sections were stained with cresyl violet and via the Fink-Heimer silver impregnation technique for degenerating neurons, fibers, and terminals. Sections from each kainate-treated mouse and controls (vehicle injections) were assigned a score from 0 (no damage) to 5 related to the quality and extent of neuronal damage. Sections with occasional single-cell degeneration, and with light or diffuse terminal degeneration in CAI or CA3, were given a score of 1 . Sections showing a small area with degenerated pyramidal cells and fibers/terminals in CA1 or CA 3 were assigned a score of 2 (mild damage). Sections with a greater area of degeneration of neurons and fibers/terminals, but still confined to one region (CA1 or CA3), were given a score of 3 (moderate damage). Sections containing neuronal cell loss and extended degeneration of neurons and fibers/ terminals in two hippocampal regions (CA1 and CA3), frequently includ-
Table 1. Relationship between $\mathrm{p53}$ genotype and seizure severity after kainate administration

\begin{tabular}{lccc} 
& \multicolumn{2}{c}{ p53 Genotype } & \\
\cline { 2 - 4 } & $+/+$ & $+1-$ & $-1-$ \\
\hline$n$ & 16 & 16 & 14 \\
Seizure rating & $2.00 \pm 0.16$ & $2.38 \pm 0.16$ & $1.79 \pm 0.24$
\end{tabular}

The behavioral response to kainate administration was assessed as described in Materials and Methods. The results depict the average seizure rating \pm SEM for each genotype. The bchavioral response was not significantly different among the three genotypes at $p>0.1$ (Pearson $\chi^{2}$ test of probability).

ing both dorsal and ventral hippocampus, were scored 4 (severe damage). Sections that exhibited substantial neuronal cell loss, degeneration of neurons and fibers/terminals in two or more hippocampal regions, and additional degeneration in other brain regions (e.g., neocortex, caudateputamen, amygdala) were given a score of 5 (extreme damage). For statistical analyses, observations were grouped into three categories, according to animals that showed little or no damage (scores 0 and 1 ), mild to moderate damage (scores 2 and 3 ), and severe damage (scores 4 and 5). Degree of damage was assessed independently by two investigators who were blind to the genetic identity of the animal.

In situ labeling of DNA fragmentation. To assess apoptotic cell death more accurately, we used the terminal transferase-mediated biotinylatedUTP nick end-labeling (TUNEL) technique (Gavrieli et al., 1992). This procedure has been widely used as an indicator of apoptotic cell death by other investigators (Symonds et al., 1994; Kasof et al., 1995; Nitatori et al., 1995; Portera-Cailliau et al., 1995). In brief, brains were fixed by cardiac perfusion of $4 \% p$-formaldehyde in $0.1 \mathrm{~m}$ phosphate buffer at 1,2 , $3,4,7$, and $10 \mathrm{~d}$ after kainate injection. The brains immediately were dissected out and post-fixed in the same fixative. The total fixation time, starting with perfusion, was 2-3 hr. The brains were washed in PBS for 2 hr. After overnight incubation in $70 \%$ ethanol, the tissues were dehydrated in a graded series of ethanol, cleared in xylenes or Hemo-De (Fisher Scientific, Pittsburgh, PA), and embedded in paraffin. Sections were cut at $6 \mu \mathrm{m}$, mounted on SuperFrost/Plus glass slides (Fisher), and baked overnight at $37^{\circ} \mathrm{C}$.

After deparaffinization and rehydration, sections were digested with proteinase $\mathrm{K}(10 \mu \mathrm{g} / \mathrm{ml}$ in distilled water $)$ for $25 \mathrm{~min}$ at room temperature (RT). Endogenous peroxidase activity was quenched in $2 \% \mathrm{H}_{2} \mathrm{O}_{2}$ in distilled water for $5 \mathrm{~min}$. Tissue sections were incubated first with terminal deoxynucleotidyl transferase (TdT) buffer [200 mM potassium cacodylate, 25 mIM Tris-Cl, 0.25 mig/ml bovine serum albumin (BSA), 1 IIIM $\mathrm{CoCl}_{2}, \mathrm{pH}$ 6.6] for $10 \mathrm{~min}$ at RT and then with $\mathrm{TdT}(0.1 \mathrm{U} / \mathrm{ml}$, Boehringer Mannheim, Indianapolis, IN) and biotin-16-deoxyuridine triphosphate (biotin-dU'I'P; $2 \mathrm{nM}$, Bochringer Mannheim) in 'I' 'I' buffer at $37^{\circ} \mathrm{C}$ for 75 min in a humidified chamber. As a negative control, sections were incubated in TdT buffer containing biotin-dUTP but lacking TdT enzyme, which did not produce any staining. The TdT reaction was stopped in a buffer of $300 \mathrm{~mm} \mathrm{NaCl}$ and $30 \mathrm{~mm}$ Na-citrate for $15 \mathrm{~min}$ at RT. Tissue sections were then blocked with 1\% BSA in PBS for 10 min at RT and

Table 2. Relationship between seizure rating and morphological damage for each $p 53$ genotype

Degree of neuromal damage (neuromal damage score)

\begin{tabular}{llll} 
Seizure rating & $\begin{array}{l}\text { p53 Genotype } \\
+/+\end{array}$ & $+/-$ & $-1-$ \\
\hline 0 & $0.0(n=0)$ & $0.0(n=0)$ & $0.0(n=2)$ \\
1 & $1.7(n=3)$ & $5.0(n=1)$ & $0.0(n=1)$ \\
2 & $2.7(n=10)$ & $2.7(n=8)$ & $1.1(n=9)$ \\
3 & $3.7(n=3)$ & $3.0(n=7)$ & $0.5(n=2)$
\end{tabular}

Seizure rating and neuronal damage score were assessed as described in Materials and Methods. Neuronal damage was assessed by cresyl violet staining and silver impregnation 1 week after kainate administration. The results depict the average neuronal damage score (scale of 0 5) observed for the indicated levels of seizure severity. Given in parentheses is the number of animals, for a given genotype, exhibiting that particular seizure rating. 


$\begin{aligned} & \text { Table 3. Relationship between p53 genotype and neuronal damage in } \\
& \text { kainate-treated mice }\end{aligned}$
\begin{tabular}{lccc} 
& Degree of neuronal damage (number of animals) \\
\cline { 2 - 4 } p53 Genotype & None/little & Mild/moderate & Severe \\
\hline$+/+(n=16)$ & $4(25 \%)$ & $8(50 \%)$ & $4(25 \%)$ \\
$+/-(n=16)$ & $3(19 \%)$ & $6(37 \%)$ & $7(44 \%)$ \\
$-/-(n=14)^{*}$ & $10(71 \%)$ & $4(29 \%)$ & $0(0 \%)$ \\
\hline
\end{tabular}

Neuronal damage was assessed as described in Materials and Methods at 1 week after kainate administration. The results depict the number of mice of each genotype that express the indicated degree of neuronal damage. The relative percentage of mice of each genotype displaying a particular degree of damage is shown in parentheses. *Differs from other genotypes at $p<0.01$ (Pearson $\chi^{2}$ test of probability).

incubated with streptavidin-biotin-peroxidase (SABC Universal, 1:125 dilution, Zymed, San Francisco, CA) in 1\% BSA-PBS for $1 \mathrm{hr}$. After two washes in PBS and one wash in $50 \mathrm{~mm}$ Tris- $\mathrm{Cl}, \mathrm{pH} 7.6$, sections were processed for a standard diaminobenzidine (DAB) chromogen reaction ( $0.05 \% \mathrm{DAB}$ and $0.0045 \% \mathrm{H}_{2} \mathrm{O}_{2}$ in $50 \mathrm{~mm}$ Tris-Cl, $\mathrm{pH} 7.6$, for $6-8 \mathrm{~min}$ at RT) and mounted in Permount.

\section{RESULTS}

\section{Behavioral response to $\mathrm{KA}$ in mice of varying p53 genotype}

Kainate injection produced seizures of comparable intensity and duration in animals irrespective of their p53 status (Table 1). A majority of animals exhibited strong to severe seizures during the first 2-3 hr after injection (Table 2). The patterns of these behavioral responses to kainate were similar to those reported previously for rats and mice (Franck et al., 1988; Tasker et al., 1991). The relative percentage of animals exhibiting severe seizures (seizure ratings 2 and 3 ) in response to kainate was 81,94 , and $79 \%$ for p53 $+/+$ mice, mice heterozygous for p53 $(+/-)$, and $-/-$ mice, respectively (Table 2 ). The absence of a significant genotype-associated difference in seizure severity suggests that the neurophysiological mechanisms underlying seizure generation are not dependent on p53 expression.

\section{The absence of p53 reduces neuronal cell death after kainate injection}

The role of $\mathrm{p} 53$ in initiating neuronal degeneration was assessed by determining the extent of kainate-mediated injury in p53 knockout mice $(-/-)$ and the corresponding $+/+$ mice. Kainate administration induced a significant degree of neuronal damage in all pyramidal cell subfields of the hippocampus (except in CA2) in $+/+$ mice (Tables 3, 4). Figures $1 C, 2 C$, and $3 C, G$ illustrate the extensive cell and terminal degeneration of pyramidal neurons in CA3, CA1, and the subiculum seen with Fink-Heimer silver impregnation at $7 \mathrm{~d}$ after kainate administration. Neuronal damage in the CA3 subfield was observed as early as $8 \mathrm{hr}$ after kainate administration. Fink-Heimer silver impregnation processing revealed significant $\mathrm{CA} 3$ subfield damage at days $1-4$ with maximal

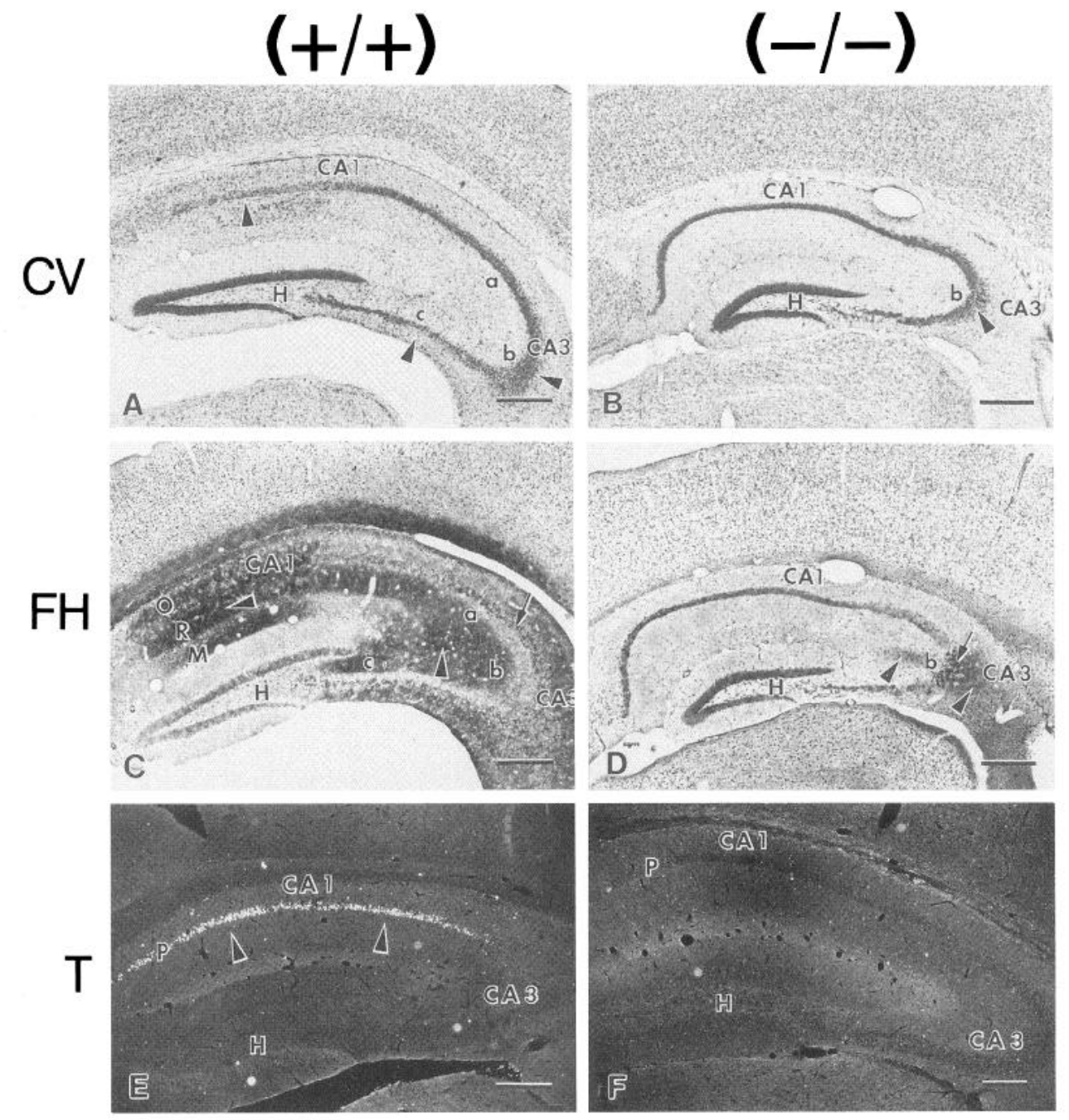

Figure 1. Photomicrographs of kainateinduced cell damage in the hippocampus of $\mathrm{p} 53+/+(A, C, E)$ and $-/-(B, D, F)$ mice. $A$, Nissl (cresyl violet)-stained section through dorsal hippocampus, showing typical pattern of cell degeneration and gliosis (arrowheads) in CAI, CA3b, and CA3c of $+/+$ mice $7 \mathrm{~d}$ after subcutaneous kainate administration. $B$, In comparable sections through hippocampus of $-1-$ mice, the damage (if present) was confined to $C A 3 b$ (arrowhead). C, Fink-Heimer impregnation shows argyrophilic pyramidal cell bodies ( $a r$ row), and degenerating fibers and terminals (arrowheads) in the $C A 1$ and $C A 3$ subfields $(a-c)$ of the wild-type mouse. Terminal degeneration was seen primarily in the dendritic regions of the stratum oriens $(O)$, stratum radiatum $(R)$, and stratum moleculare $(M)$. D, In p53-deficient mice, degeneration (when present) was restricted to $C A 3 b . E, F$, TUNEL labeling (as seen in dark-field), indicative of DNA fragmentation in apoptotic cells (arrowheads), is observed in stratum pyramidale $(P)$ of the $C A 1$ region of p53 $+/+$ mice $(E)$ and is absent in p53-/- mice $(F) 4 \mathrm{~d}$ after kainate administration. Abbreviations: $C A 1, C A 3 a, b, c$ hippocampal subfields; $H$, dentate hilus; $C V$, cresyl violet stain; $F H$, Fink-Heimer impregnation; $T$, TUNEL labeling. Scale bars, $300 \mu \mathrm{m}$. 
Figure 2. Photomicrographs of kainateinduced cell damage in the CA1 subfield of $\mathrm{p} 53+1+(A, C, E, G)$ and $-1-(B, D, F, H)$ mice. $A, B$, Low-power view of the CA1 subfield stained with cresyl violet 1 week after kainate administration. Note the presence of pyknotic cells and gliosis in the p53 $+/+$ mice $(A)$, but the normal appearance of CA1 in $-/-$ mice (B). $C, D$, Argyrophilic pyramidal cell bodies (arrows) and degenerating fibers and terminals (arrowheads) are seen in Fink-Heimer-impregnated material in the p53 $+/+$ mice $(C)$, but are absent in sections from the p53 $-/-$ mice $(D) . E, F$, Higher-power micrographs showing neurons with shrunken cell bodies and pyknotic nuclei (arrows) in p53 +/+ mice $(E)$, but the absence of such apoptotic figures in p53-/- mice $(F)$. Pyramidal cells $(P C)$ in the CA1 region of kainate-treated $-1-$ mice retain a large, pale, oval-shaped nucleus without any signs of chromatin condensation. $G, H$, Significant numbers of TUNEL-labeled cells (arrows) are dispersed throughout the CA1 subfield of p53 $+/+$ mice $(G)$; no TUNEL-labeled cells were observed in p53 $-/-$ mice $(H) 4 \mathrm{~d}$ after kainate administration. Abbreviations: $M$, stratum moleculare; $O$, stratum oriens; $P$, stratum pyramidale; $R$, stratum radiatum; $C V$, cresyl violet stain; $F H$, FinkHeimer impregnation; $T$, TUNEL labeling. Scale bars: $A-D, 100 \mu \mathrm{m} ; E, F, 20 \mu \mathrm{m} ; G$, $H, 25 \mu \mathrm{m}$.

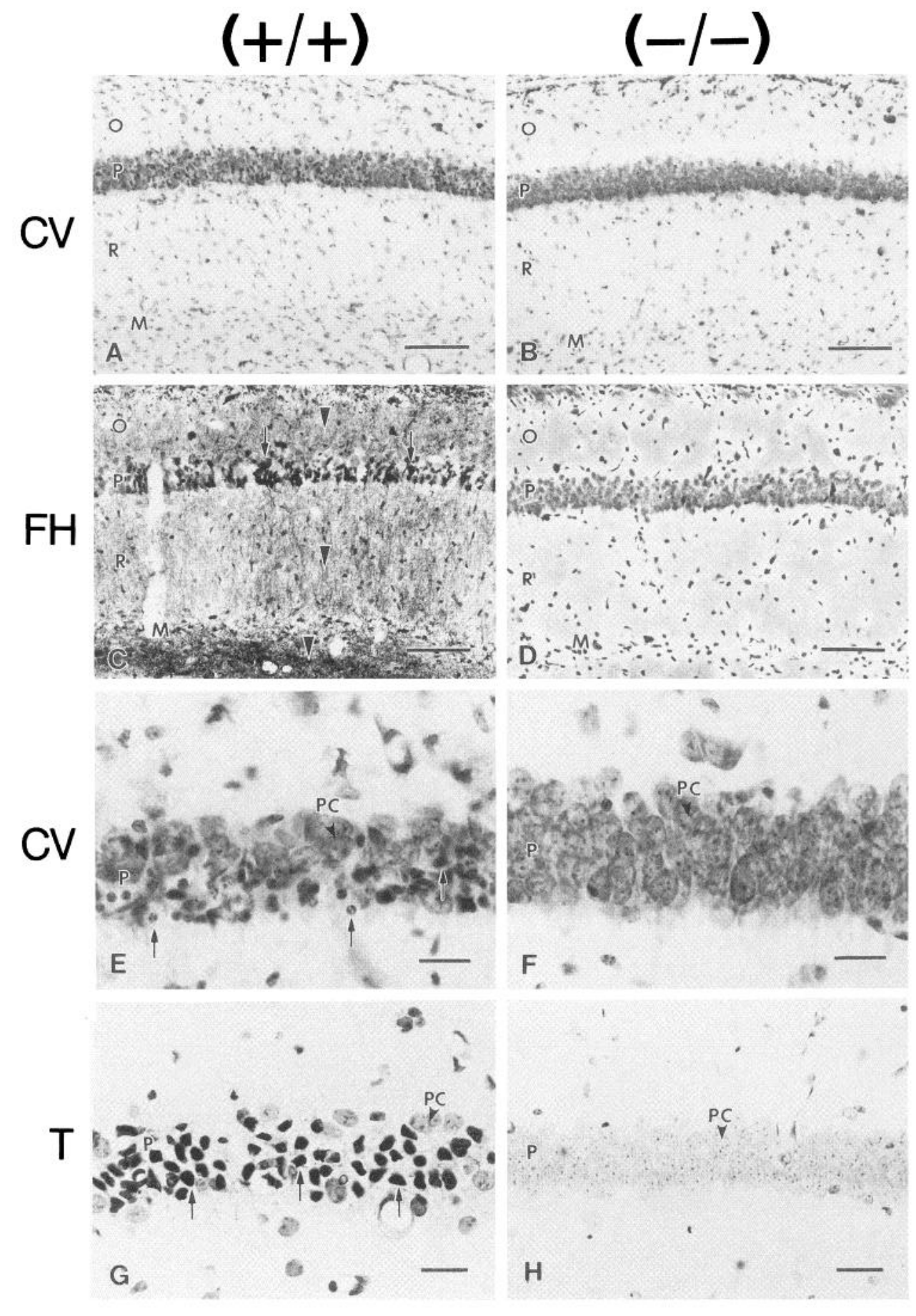

$(-/-)$ damage seen at 5-7 d after kainate administration. By day 10 , degenerating cell bodies were barely detectable (none were detected by day 12) in the CA3 subfield with Fink-Heimer staining. Neuronal damage in the CA1 subfield was not observed until $3 \mathrm{~d}$ after kainate administration but also reached maximal levels at 1 week after kainate administration. Damage was observed in both dorsal and ventral regions of the hippocampus but appeared to be somewhat more severe in dorsal hippocampus (Table 4). Damage to the dentate hilus was observed occasionally, whereas the CA2 subfield appeared to be resistant to the excitotoxic effects of kainate, as reported previously (Nadler et al., 1978). Among the degenerating cell populations, cresyl violet staining showed neurons exhibiting chromatin condensation, consistent with the pro- cess of apoptotic cell death. Cells displaying this morphology, however, were restricted to the CA1 subfield of wild-type mice (Fig. 2E).

In p53 $+/+$ mice, kainate treatment also induced neuronal degeneration and cell loss in multiple extrahippocampal brain regions (Table 4, Fig. 4). Kainate-sensitive neurons were identified in the amygdala, caudate-putamen, thalamus, and cortex based on the silver impregnation method (Fig. $4 A-D$ ). However, the hippocampus appeared to be the brain region most vulnerable to the effects of kainate, because neuronal degeneration was confined to the hippocampus when lower doses of kainate (25 $\mathrm{mg} / \mathrm{kg}$ ) were administered (data not shown).

The pattern and extent of neuronal damage did not differ 


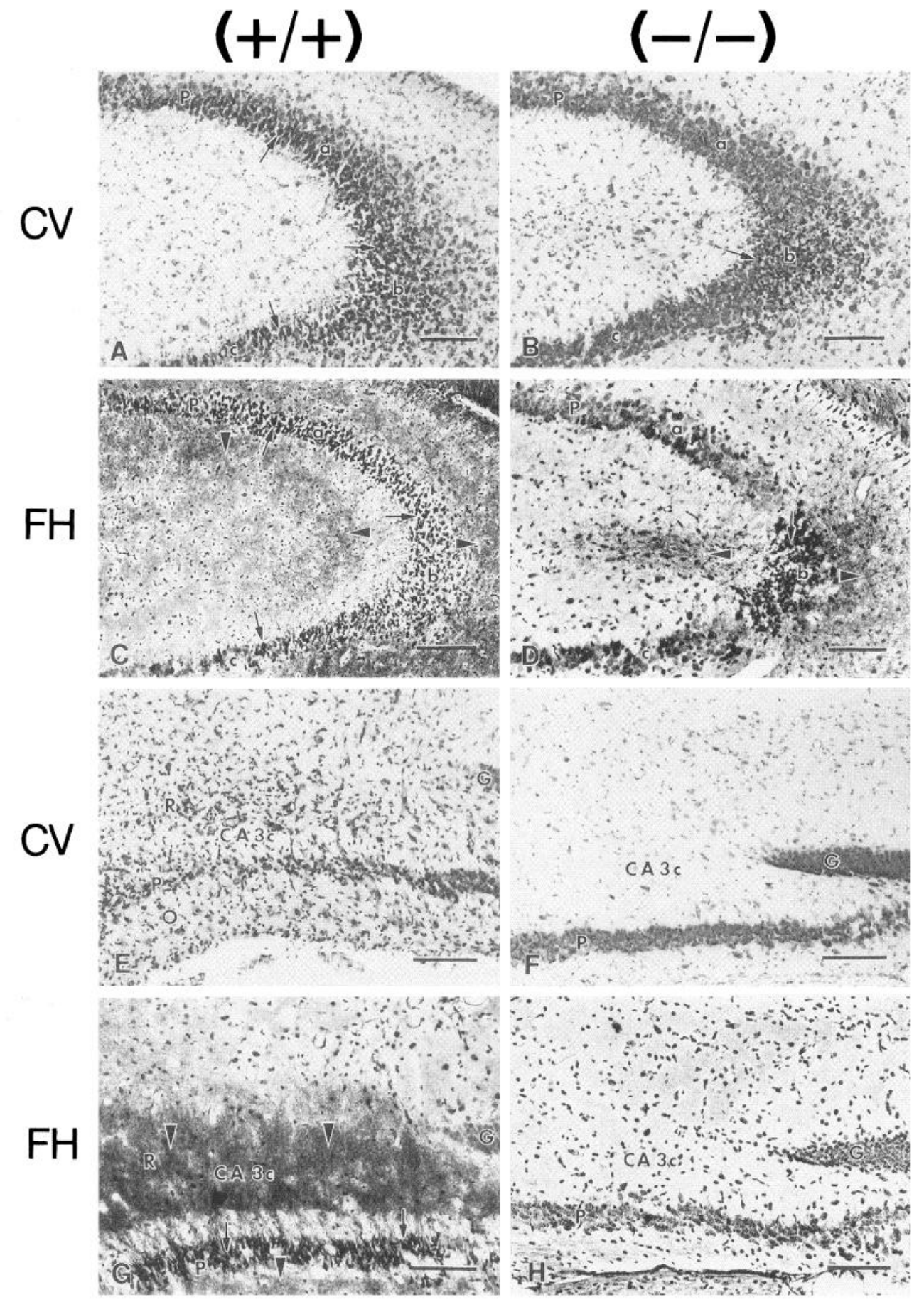

Figure 3. Photomicrographs of kainateinduced cell damage in the CA3 subfield of $\mathrm{p} 53+/+(A, C, E, G)$ and $-/-(B, D, F, H)$ mice. $A, B$, Cresyl violet stain of the CA3 subfields $(a-c) 1$ week after kainate administration, showing degenerated pyramidal cells (arrows) in CA3a-c of p53 $+1+$ mice $(A)$ and CA $3 b$ of p53-1- mice $(B) . C, D$, Many argyrophilic pyramidal cell bodies (arrows) and degenerating fibers/terminals (arrowheads) are seen in Fink-Heimerimpregnated sections through subfields $\mathrm{CA} 3 a$ and $\mathrm{CA} 3 b$ of $\mathrm{p} 53+/+$ mice $(C)$; in contrast, only mild damage is observed in the CA $3 b$ subfield (and in only one-third of the animals) in $\mathrm{p} 53-/-$ mice $(D) . E, F$, In subfield CA3c, Nissl staining revealed substantial pyramidal cell loss and gliosis in the $C A 3 c$ subfield of $\mathrm{p} 53+/+$ hippocampus $(E)$; such damage of pyramidal cells is absent in p53 $-/-$ mice $(F)$. $G, H$, Silver impregnation confirmed massive kainateinduced damage to pyramidal cell bodies (arrows) and fibers/terminals (arrowheads) in the $C A 3 c$ subfield in $\mathrm{p} 53+/+$ mice $(G)$; the silver impregnation method showed no such signs of degeneration in $C A 3 c$ in 553 $-/-$ mice $(H)$. Abbreviations: $G$, granule cell layer of the dentate gyrus; $O$, stratum oriens; $P$, stratum pyramidale; $R$, stratum radiatum. Scale bars: $A-D, 150 \mu \mathrm{m} ; E-H$, $100 \mu \mathrm{m}$. significantly between $+/+$ and $+/-$ mice (Tables $2-4$ ). This result implies the absence of a gene dosage effect and demonstrates that the presence of a single p53 gene is sufficient to confer neuronal vulnerability in response to kainate.

p53 - /- mice were resistant to kainate-induced cell death (Tables 2-4). Nearly two-thirds (9/14) of the p53 -/- mice displayed no evidence of neuronal damage or degeneration in response to kainate administration (Table 4); in the remaining p53 - /- mice, damage was mild or moderate, but never severe. At 1 week after kainate treatment, the average neuronal damage rating for $\mathrm{p} 53-/-$ mice $(0.78 \pm 0.26)$ was almost 3.5 -fold lower than the damage rating for $\mathrm{p} 53+/+(2.56 \pm 0.43)$ or $+/-(2.81 \pm$ $0.40)$ mice. Even $12 \mathrm{~d}$ after kainate administration, most p53 -/- mice did not exhibit evidence of neuronal or terminal degeneration; in contrast, damage was seen as early as $8 \mathrm{hr}$ after kainate administration in the wild-type mice and was maximal 5-7 d after kainate administration. When damage was observed in $-1-$ mice, the cells most consistently affected were in the CA3b subfield of the hippocampus, where a small region of pyknotic neurons was seen (Fig. 3B,D). Damage to this CA3b subfield was restricted to the dorsal hippocampus. The other hippocampal subfields did not show damage (Figs. $2 D, 3 F, H$ ), with the exception of two animals that showed several isolated degenerating cells in the CA1 subfield (data not shown). No evidence of neuronal damage or cell loss was observed in any extrahippocampal region of $-1-$ mice (Table 4, Fig. 4). The limited damage that was present in the 
Table 4. Regional distribution of neuronal damage after kainate administration to mice of varying $p 53$ genotype

\begin{tabular}{|c|c|c|c|c|c|c|}
\hline \multirow{4}{*}{$\frac{\text { Region }}{\text { Hippocampus }}$} & \multicolumn{6}{|c|}{ Neuronal damage (no. animals) } \\
\hline & \multicolumn{6}{|c|}{ Genotype } \\
\hline & \multicolumn{2}{|c|}{$+/+(n=16)$} & \multicolumn{2}{|c|}{$+/-(n=16)$} & \multicolumn{2}{|c|}{$-/-(n=14)$} \\
\hline & Dorsal & Ventral & Dorsal & Ventral & Dorsal & Ventral \\
\hline CA1 & 10 & 6 & 11 & 8 & $2^{a}$ & 0 \\
\hline $\mathrm{CA2}$ & 0 & 1 & 0 & 0 & 0 & 0 \\
\hline $\mathrm{CA} 3 \mathrm{a}$ & 3 & 6 & 2 & 9 & 0 & 0 \\
\hline $\mathrm{CA} 3 \mathrm{~b}$ & 11 & 6 & 13 & 8 & 5 & 0 \\
\hline $\mathrm{CA} 3 \mathrm{c}$ & 3 & 3 & 2 & 2 & 0 & 0 \\
\hline Dentate gyrus/hilus & \multicolumn{2}{|r|}{3} & \multicolumn{2}{|c|}{4} & \multicolumn{2}{|r|}{0} \\
\hline
\end{tabular}

Extrahippocampal

\begin{tabular}{llll}
\hline Cortex & 8 & 7 & 0 \\
Thalamus & 6 & 4 & 0 \\
Caudate-putamen & 8 & 6 & 0 \\
Amygdala & 6 & 5 & 0
\end{tabular}

The total number of animals cxhibiting neuronal damage of any degree, for each genotype, was: $+/+, 13 / 16 ;+/-, 14 / 16 ;-/-, 5 / 14$. Neuronal damage was assessed by cresyl violet staining and silver impregnation 1 week after kainate administration.

"These two animals displayed a lew, isolated damaged cells in CA1 and belong to the group of five p53 -/- animals that exhibited damage in CA3.

hippocampus of p53 $-1-$ mice could not be attributed to a lower level of seizure activity; when animals were matched for comparable seizure behavior scores, p53 -/- mice displayed significantly less neuronal damage than mice containing p53 alleles (Table 2). These results strongly imply that p53 influences neuronal viability after the induction of seizure activity.

\section{p53 enhances neuronal apoptosis}

p53 has been shown to promote apoptotic cell death in a number of non-neuronal cell types. Therefore, we investigated the possibility that p53 promoted irreversible neuronal injury after kainate administration by inducing neuronal apoptosis. The TUNEL labeling procedure, which is diagnostic for the appearance of DNA fragmentation, was used to identify apoptotic neurons (Wood et al., 1993; Gold et al., 1994; Symonds et al., 1994; Kasof et al., 1995; Portera-Cailliau et al., 1995). Labeled cells were not observed in the hippocampus of nontreated $+/+$ mice or wild-type control mice (saline-injected; data not shown). However, significant numbers of hippocampal pyramidal neurons were labeled intensely by the TUNEL method at 3 and $4 \mathrm{~d}$ after kainate treatment (Figs. $1 E, 2 G)$. Labeled cells were not detected before or after this time. Interestingly, in the hippocampus, cells labeled by the TUNEL method were detected almost exclusively in the CA1 subfield despite the large number of degenerating neurons detected in the CA3 subfields by the cresyl violet stain and the silver impregnation method. Cresyl violet staining confirmed that neurons exhibiting morphological evidence of apoptosis-condensed nuclei and shrunken cell bodies-were restricted to the CA1 subfield of the hippocampus (Figs. 2E, 3A,E). A small number of labeled cells was observed in the CA3b subfield in a single animal. In contrast to the wild-type mice, CA1 pyramidal neurons in the hippocampus of p53 - / - mice did not exhibit apoptotic labeling after kainate administration (Fig. $1 F, 2 H$ ). As a positive control for this "negative" finding, a section of hippocampus from a kainate-treated p53 - /- mouse was incubated with DNase to generate DNA breaks in every cell; TUNEL labeling after DNase treatment produced staining in every cell (data not shown), confirming that the labeling procedure identified DNA breaks in $-1-$ mouse sections.

Extrahippocampal regions in wild-type mice also exhibited evidence of apoptosis after kainate injection. The kainate-sensitive neurons in the caudate-putamen, amygdala, and the thalamus of p53 $+/+$ mice showed TUNEL labeling (data not shown), consistent with the results of the silver impregnation method. In marked contrast, p53 $-/-$ mice did not display evidence of TUNEL labeling in any brain region examined after kainate administration.

\section{DISCUSSION}

We have used transgenic mice deficient in one or both p53 alleles to examine the effect of p53 loss on neuronal viability after excitotoxic injury. A relationship between p53 expression and irreversible neuronal injury has been suggested by the recent finding that kainate administration induced p53 expression in neurons exhibiting morphological evidence of damage (Sakhi et al., 1994). Evidence obtained from the present study suggests the following: (1) p53 promotes irreversible neuronal damage after excitotoxic injury; (2) p53 may confer susceptibility to cell death by multiple pathways, for example, apoptosis versus necrosis; and (3) neuronal cell death also can be initiated by p53-independent pathways as evidenced by apoptotic cell death observed in a tumor-bearing $-1-$ mouse (see below). Because the lack of p53 did not significantly alter the intensity or duration of seizures induced by kainate, we conclude that p53 expression does not play a role in the generation of these seizures; our results suggest that p53 compromises neuronal viability after seizure induction. Whereas it is not yet clear whether p53 induction represents a generalized response to a range of CNS insults, it is clear from the present study that $\mathbf{p 5 3}$ can modulate neuronal viability in response to excitotoxic insult.

The precise nature of the cell death pathway activated in response to p53 induction has not yet been determined. There is presently a diversity of opinions regarding the type of cell death that is activated in response to CNS injury and disease. Whereas excitotoxic injury to the hippocampus, analogous to the model used in the present study, has been reported to involve only necrosis of pyramidal neurons (Ignatowicz et al., 1991), there is also recent evidence for induction of apoptosis (Kasof et al., 1995). Apoptotic cell death also has been demonstrated in the striatum after direct injection of excitotoxin (Portera-Cailliau et al., 1995) and in CA1 pyramidal neurons after transient ischemia (Nitatori et al., 1995). An apoptotic mechanism of cell death also has becn proposed for the demise of striatal spiny ncurons in Huntington's disease (Portera-Cailliau et al., 1995).

The two major types of cell death have been distinguished based on specific morphological criteria. Apoptosis has been characterized, in part, by perinuclear chromatin condensation and endonuclease-mediated internucleosomal DNA fragmentation into a "ladder" pattern. Nuclear changes indicative of DNA fragmentation have been detected in situ, using the TUNEL method (Gavrieli et al., 1992). In the present study, TUNELpositive neurons were observed only in kainate-treated mice containing p53. TUNEL-positive cells in the hippocampus were restricted almost entirely to the CA1 subfield despite the significant degree of degeneration detected in CA3 pyramidal neurons using the silver impregnation method. These results suggest that p53 promotes cell death via multiple pathways-apoptotic cell death in CA1 neurons and necrotic cell death in CA3 neurons. The 
$(+/+)$
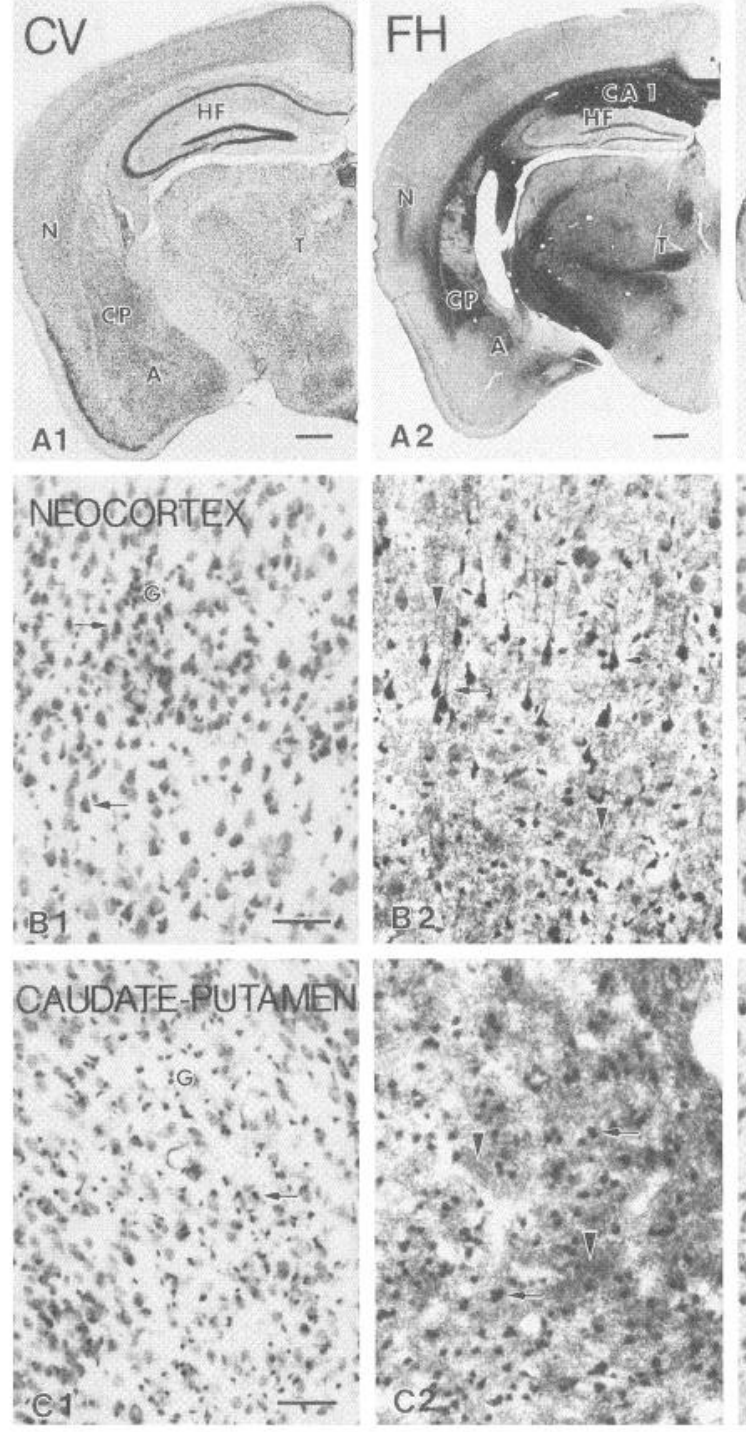
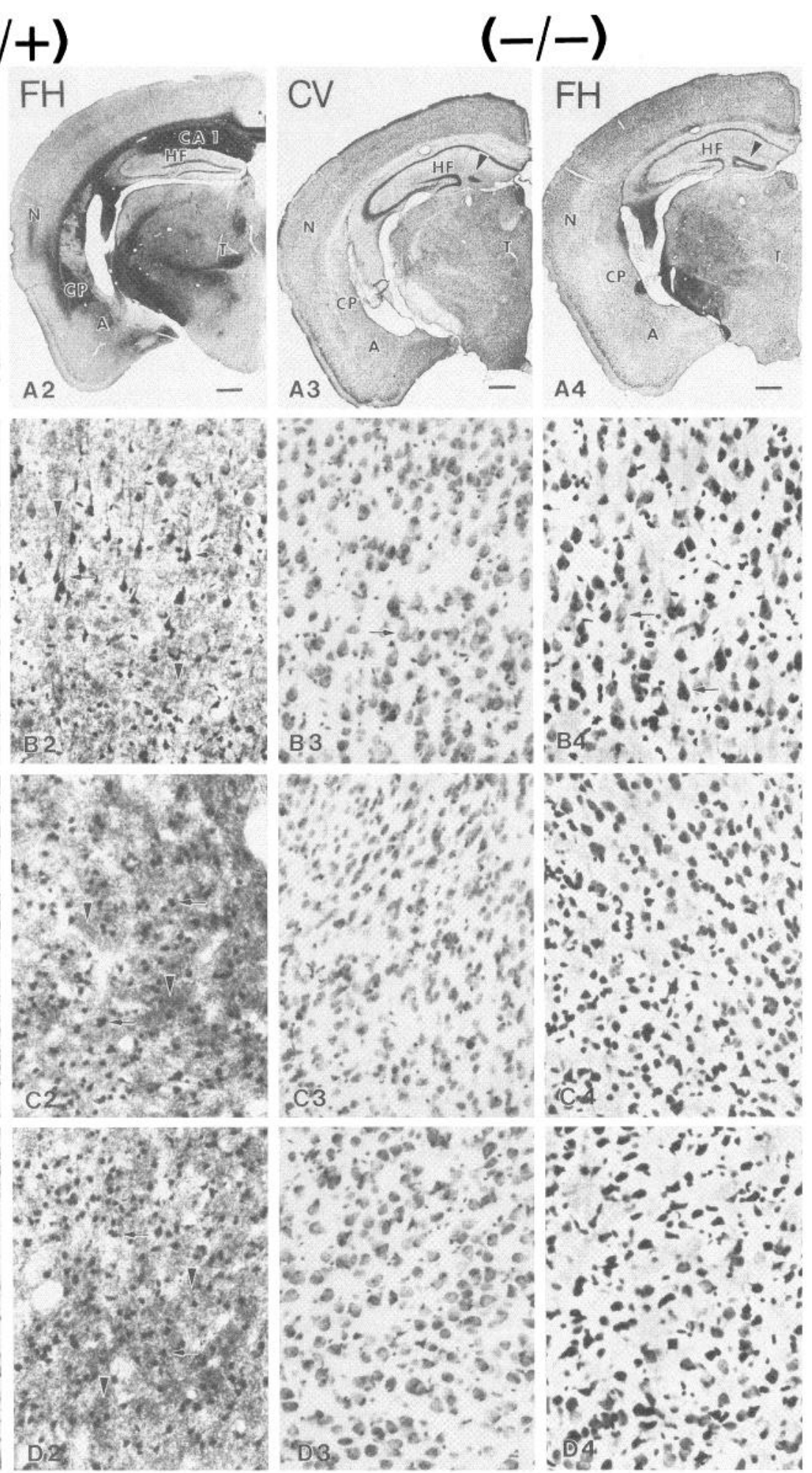

A4
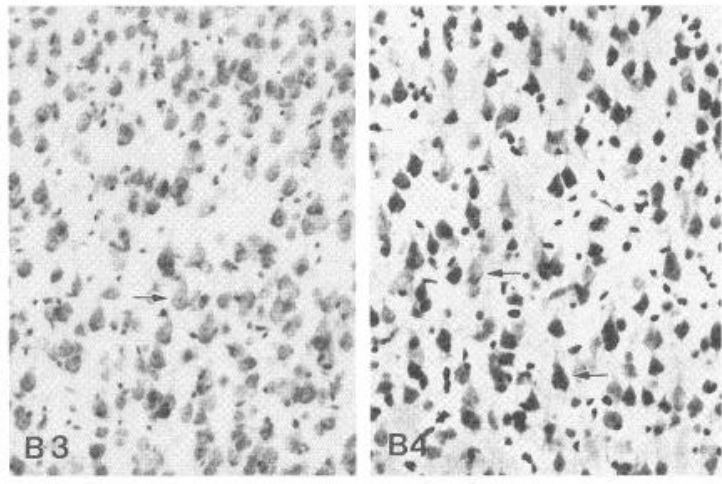

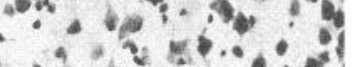

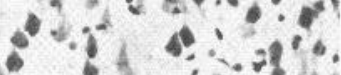

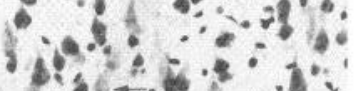
$-5, \frac{1}{5}, 4,8 x$

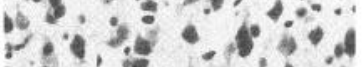

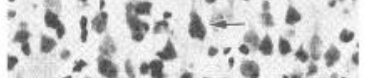
B $3: 2$.

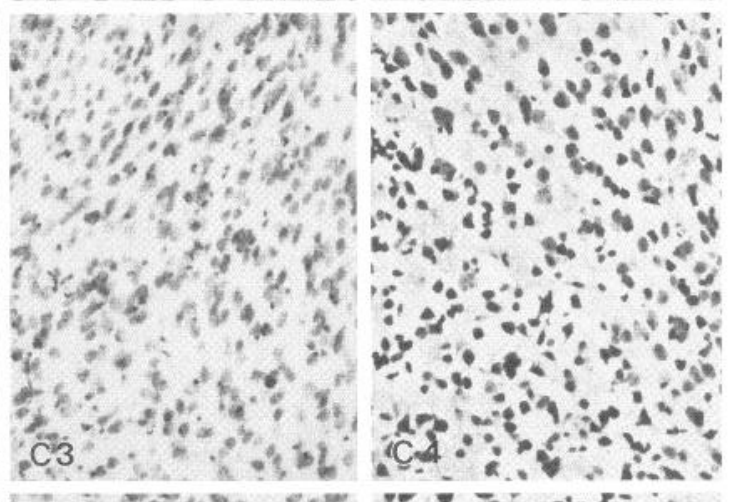

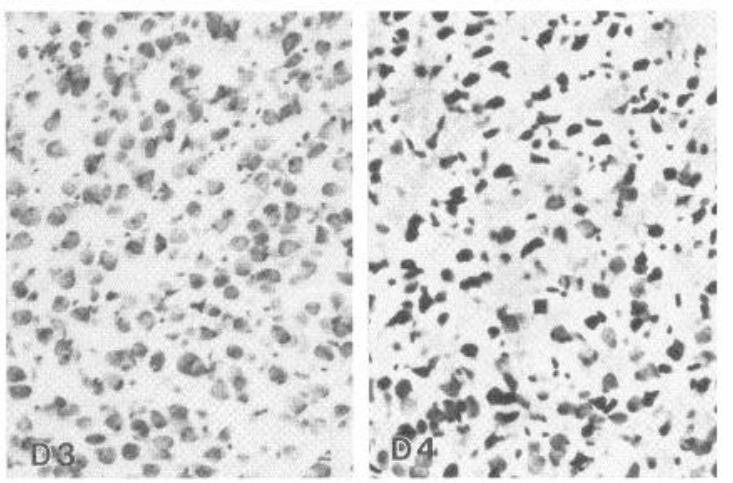

Figure 4. Regional distribution of kainate-induced cell damage in p53 $+1+$ and $-1-$ mice. $A 1, A 2$, Cresyl violet $(\mathrm{CV})$ staining and Fink-Heimer $(\mathrm{FH})$ silver impregnation reveal the wide extent of extrahippocampal damage observed in p $53+/+$ mice. Significant degeneration is seen with the Fink-Heimer method $(A 2)$ in the parietal neocortex $(N)$, amygdala $(A)$, caudate-putamen $(C P)$, and thalamus $(T)$. Extensive damage to the hippocampal formation is also present ( $H F-C A 1$ subregion). $A 3, A 4$, Cresyl violet staining and Fink-Heimer impregnation show little extrahippocampal damage in p53 - - mice. Note, however, the development of an aberrant granule cell formation in the dentate gyrus of the p $53-/-$ animal $(A 3, A 4$, arrowhead). Higher-power micrographs through selected brain regions show cresyl violet staining (columns 1 and 3 ) and Fink-Heimer impregnation (columns 2 and 4 ) in p53 $+/+$ (columns 1 and 2 ) and p53-/- (columns 3 and 4 ) animals. Row B, Neocortex; row C, caudate-putamen; row D, amygdala. Only the p53 +/+ mice showed significant cell loss, pyknotic cells (arrows) and degenerating fibers/terminals (arrowheads). Normal pyramidal cells in p53 - / mice are denoted by arrows in B3 and B4. Limited staining by the silver impregnation method is occasionally observed in normal fibers contained within white matter tracts (e.g., corpus callosum, fimbria, internal capsule) of nontreated animals (Heimer, 1970) as seen in p53-/- animals (column 4). Scale bars: Al-A4, 500 $\mu$ m; $B 1-D 4,50 \mu \mathrm{m}$. 
absence of TUNEL-positive neurons in p53 - / - mice after kainate administration indicates that the regionalized degeneration observed in $\mathrm{CA} 3 \mathrm{~b}$, as revealed by the silver impregnation method, is likely caused by necrotic cell death.

Interestingly, one p53 $-/-$ mouse presented with a spontaneous brain tumor that severely compressed both hippocampi. This animal exhibited significant numbers of TUNEL-positive neurons in the subiculum and CA1 subfield. Because this was the only p53 $-/-$ mouse to exhibit TUNEL labeling, the induction of apoptotic cell death in this mouse could have been caused by compressioninduced ischemia or by tumor-derived factors. This result demonstrates that, under the appropriate circumstances, it is possible to induce neuronal apoptosis in the absence of p53, and it raises the intriguing possibility that different kinds of brain pathology may produce ncuronal degencration by initiating distinct, nonoverlapping cell death pathways. For example, the absence of p53 does not confer protection on embryonic sensory and sympathetic neurons after the withdrawal of neurotrophins (Davies and Rosenthal, 1994). In addition, Bcl-2 has been found to protect neurons from glutamate-induced damage but not damage induced by the amyloid- $\beta$ protein (Behl et al., 1993). Irrespective of the lype of cell death that ultimately ensues (apoptosis vs necrosis), the initiation of irreversible neuronal injury appears to involve specific changes in gene expression. The results of the present study suggest that p53 gene expression is related to at least one pathway regulating neuronal vulnerability after injury.

The mechanism by which p53 promotes neuronal cell death is not understood. The p53 protein can function as a site-specific transactivator or repressor of transcription (Kern et al., 1991; Seto et al., 1992). Two genes susceptible to regulation by p53 are Bcl-2 and Bax, which cxhibit repression and activation, respectively (Miyashita et al., 1994a,b, 1995). Bcl-2 blocks cell death after a variety of stimuli (Vaux et al., 1988; Allsopp et al., 1993; Behl et al., 1993; Hockenbery et al., 1993; Kane et al., 1993; Martinou et al., 1994; Strasser et al., 1994), whereas overexpression of Bax accelerates apoptotic cell death (Oltvai et al., 1993). The susceptibility of cells to an apoptotic stimulus is thought to be deterInined, in part, by the ratio of $\mathrm{Bcl}-2$ and Bax proteins. If $\mathrm{p} 53$ induction causes $\mathrm{Bcl}-2$ repression and Bax activation, then Bax would predominate, yielding a condition that accelerates cell death. However, the mechanism by which $\mathrm{Bcl}-2$ blocks cell death is also poorly understood. One potential consequence of a reduction in $\mathrm{Bcl}-2$ could be an elevation in the intracellular levels of free radicals, because $\mathrm{Bcl}-2$ has been reported to suppress the generation of reactive oxygen species (Hockenbery et al., 1993; Kane et al., 1993).

Although Bcl-2 is not expressed in adult hippocampal ncurons (Merry et al., 1994), Bcl- $\mathrm{x}_{\mathrm{L}}$, a Bcl-2-related gene that blocks cell death, recently has been identified in these cells (Boise et al., 1993; Krajewski et al., 1994). Mice deficient in Bcl-x display extensive apoptotic cell death in immature neurons, underscoring the importance of $\mathrm{Bcl}-\mathrm{x}_{\mathrm{L}}$ to neuronal survival (Motoyama et al., 1995). The Bax protein also is localized to neurons (Miyashita et al., 1994a; Krajewski el al., 1994b), and preliminary results from our laboratory have demonstrated that Bax immunoreactivity is elevated in neurons of $\mathrm{p} 53+/+$ mice after kainate administration (Y. Kinoshita and R. Morrison, unpublished data). Therefore, components of a p53-related cell death pathway are present in hippocampal pyramidal neurons.

The signal responsible for inducing p53 in injured neurons is not known presently. When proliferating cells sustain DNA damage, the p53 protein is accumulated, causing either cell cycle arrest or apoptosis. In the absence of growth arrest at the G1/S interface, cells may lack the opportunity to repair damaged DNA before progressing into the DNA-synthetic phase of the cell cycle. Thus, the loss of wild-type $\mathrm{p} 53$ function may render cells more susceptible to genetic instability, predisposing them to neoplastic transformation. Because neurons are postmitotic cells, the generation of extensive DNA damage may allow for only a single outcome, cell death. Mechanisms for sensing DNA damage and rcgulating DNA repair in neurons have not been elucidated. Recent evidence suggests that DNA strand breaks, but not other DNA lesions, are capable of inducing p53 accumulation (Jayaraman and Prives, 1995; Lee et al., 1995). Any form of neuronal injury that produced an excess of free radicals could generate DNA strand breaks (Halliwell and Gutteridge, 1989), which then could provide a signal for activating p53.

The extent of DNA damage that is required for p53 activation is not known, but it is conceivable that the critical degree of damage is sufficient to preclude maintenance of appropriate transcriptional activity. Such an insult could prove deleterious to more than just the injured cells, because a given neuron shares complex connections with multiple cell types. Indeed, it may prove more beneficial to remove the injured member of the pathway than to retain it in a functionally compromised form. Appreciation of this complex and relatively unique characteristic of neurons could become an issue as therapies for promoting neuronal survival after a stroke or ischemic injury are targeted to components of a cell death pathway that is activated by DNA damage. Because a vast majority of p53-deficient hippocampal neurons survive an injury (excitotoxic insult) that presumably damages DNA and activates p53 in wild-type mice, it will be important to determine whether neuronal survival is maintained at the expense of functional integrity. If neuronal function is not compromised, then p53 and related members of this pathway may provide new targets for reversing the excitotoxin-mediated neuronal degeneration that is thought to be related to several neuropathological disorders.

\section{REFERENCES}

Allsopp TE, Wyatt S, Paterson HF, Davies AM (1993) The protooncogene bcl-2 can selectively rescue neurotrophic factor-dependent neurons from apoptosis. Cell 73:295-307.

Appel SH (1981) A unifying hypothesis for the cause of amyotrophic lateral sclerosis, parkinsonism, and Alzheimer's disease. Ann Neurol 10:499-505.

Behl C, Hovey L, Krajewski S, Schubert D, Reed JC (1993) Bcl-2 prevents killing of ncuronal cells by glutamatc but not by amyloid beta protein. Biochem Biophys Res Commun 197:949-956.

Boise LH, González-García M, Postema CE, Ding L, Lindsten T, Turka LA, Mao X, Nuñez G, Thompson CB (1993) Bcl-x, a bcl-2-related gene that functions as a dominant regulator of apoptotic cell death. Cell 74:597-608.

Bristow RG, Jang A, Peacock J, Chung S, Benchimol S, Hill RP (1994) Mutant p53 increases radioresistance in rat embryo fibroblasts simultaneously transfected with HPV16-E7 and/or activated H-ras. Oncogene 9:1527-1536.

Davies AM, Rosenthal A (1994) Neurons from mouse embryos with a null mutation in the tumour suppressor gene p53 undergo normal cell death in the absence of neurotrophins. Neurosci Lett 182:112-114.

Donehower LA, Harvey M, Slagle BL, McArthur MJ, Montgomery Jr CA, Butel JS, Bradley A (1992) Mice deficient for p53 are developmentally normal but susceptible to spontaneous tumours. Nature 356:215-221.

Fisher DE (1994) Apoptosis in cancer therapy: crossing the threshold. Cell 78:539-542.

Franck JE, Kunkel DD, Baskin DG, Schwartzkroin PA (1988) Inhibition in kainate-lesioned hyperexcitable hippocampi: physiologic, autoradiographic, and immunocytochemical observations. J Neurosci 8:1991-2002. 
Gavrieli Y, Sherman Y, Ben-Sasson SA (1992) Identification of programmed cell death in situ via specific labeling of nuclear DNA fragmentation. J Cell Biol 119:493-501.

Gold R, Schnied M, Giegerich G, Breitschopf H, Hartung HP, Toyka KV, Lassmann H (1994) Differentiation between cellular apoptosis and necrosis by the combined use of in situ tailing and nick translation techniques. Lab Invest 71:219-225.

Greenblatt MS, Bennett WP, Hollstein M, Harris CC (1994) Mutations in the p53 tumor suppressor gene: clues to cancer etiology and molecular pathogenesis. Cancer Res 54:4855-4878.

Halliwell B, Gutteridge JMC (1989) Free radicals in biology and medicine, 2nd Fd. Oxford: Clarendon.

Harvey M, McArthur MJ, Montgomery Jr CA, Butel JS, Bradley A, Donehower LA (1993) Spontaneous and carcinogen-induced tumorigenesis in p53-deficient mice. Nature Genet 5:225 229.

Heimer L (1970) Selective silver-impregnation of degenerating axoplasm. In: Contemporary research methods in neuroanatomy (Nauta WJH, Ebbesson SOE, eds), pp 106-131. Berlin: Springer.

Hockenbery DM, Oltvai ZN, Yin X, Milliman CL, Korsmeyer SJ (1993) $\mathrm{Bcl}-2$ functions in an antioxidant pathway to prevent apoptosis. Cell $75: 241-251$

Ignatowicz E, Vezzani A-M, Rizzi M, D'Incalci M (1991) Nerve cell death induced in vivo by kainic acid and quinolinic acid does not involve apoptosis. NeuroReport 2:651-654.

Jacks T, Remington L, Williams BO, Schmitt EM, Halachmi S, Bronson RT, Weinberg RA (1994) Tumor spectrum analysis in p53-mutant mice. Curr Biol 4:1-7.

Jayaraman L, Prives C (1995) Activation of p53 sequence-specific DNA binding by short single strands of DNA requires the p53 C-terminus. Cell 81:1021-1029.

Kane DJ, Sarafian TA, Anton R, Hahn H, Gralla EB, Valentine JS, Örd T, Bredesen DE (1993) Bcl-2 inhibition of neural death: decreased generation of reactive oxygen species. Science 262:1274-1277.

Kasof GM, Mandelzys A, Maika SD, Hammer RE, Curran T, Morgan JI (1995) Kainic acid-induced neuronal death is associated with DNA damage and a unique immediate-early gene response in c-fos-lacZ transgenic rats. J Neurosci 15:4238-4249.

Kern SE, Kinzler KW, Bruskin A, Jarosz D, Friedman P, Prives C, Vogelstein B (1991) Identification of p53 as a sequence-specific DNAbinding protein. Science 252:1708-1711.

Krajewski S, Krajewska M, Shabaik A, Miyashita T, Wang HG, Reed JC (1994b) Immunohistochemical determination of in vivo distribution of Bax, a dominant inhibitor of Bcl-2. Am J Pathol 145:1323-1333.

Krajewski S, Krajewska M, Shabaik A, Wang HG, Irie S, Fong L, Reed JC (1994a) Immunohistochemical analysis of in vivo patterns of bcl-x expression. Cancer Res 54:5501-5507.

Lee S, Elenbaas B, Levine A, Griffith J (1995) p53 and its $14 \mathrm{kDa}$ C-terminal domain recognize primary DNA damage in the form of insertion/deletion mismatches. Cell 81:1013-1020.

London ED, Coyle JT (1979) Specific binding of $\left[{ }^{3} \mathrm{H}\right]$ kainic acid to receptor sites in rat brain. Mol Pharmacol 15:492-505.

Lowe SW, Schmitt EM, Smith SW, Osborne BA, Jacks T (1993) p53 is required for radiation-induced apoptosis in mouse thymocytes. Nature 362:847-849.

Malkin D, Li F, Strong L, Fraumeni J, Nelson C, Kim D, Kassel J, Gryka M, Bischoff F, Tainsky M, Friend S (1990) Germ line p53 mutations in a familial syndrome of breast cancer, sarcomas, and other ncoplasms. Science 250:1233-1238.

Martinou J, Dubois-Dauphin M, Staple JK, Rodriguez I, Frankowski H, Missotten M, Albertini P, Talabot D, Catsicas S, Pietra C, Huarte J (1994) Overexpression of bcl-2 in transgenic mice protects neurons from naturally occurring cell death and experimental ischemia. Neuron 13:1017-1030.

Merry DE, Veis DJ, Hickey W F, Korsmeyer SJ (1994) Bcl-2 protein expression is widespread in the developing nervous system and retained in the adult PNS. Development 120:301-311.

Miyashita T, Reed JC (1995) Tumor suppressor p53 is a direct transcriptional activator of the human bax gene. Cell 80:293-299.
Miyashita T, Krajewski S, Krajewska M, Wang HG, Lin HK, Liebermann DA, Hoffman B, Reed JC (1994a) Tumor suppressor p53 is a regulator of bcl-2 and bax gene expression in vitro and in vivo. Oncogene 9:1799-1805.

Miyashita T, Harigai M, Hanada M, Reed JC (1994b) Identification of a p53-dependent negative response element in the bcl-2 gene. Cancer Res 54:3131-3135.

Motoyama N, Wang F, Roth KA, Sawa H, Nakayama K, Nakayama K, Negishi I, Senju S, Zhang Q, Fujii S, Loh DY (1995) Massive cell death of immature hematopoietic cells and neurons in Bcl-x-deficient mice. Science 267:1506-1510.

Nadler JV, Perry BW, Cotman CW (1978) Intraventricular kainic acid preferentially destroys hippocampal pyramidal cells. Nature 271:676-677.

Nitatori T, Sato N, Waguri S, Karasawa Y, Araki H, Shibanai K, Kominami E, Uchiyama Y (1995) Delayed neuronal death in the CA1 pyramidal cell layer of the gerbil hippocampus following transient ischemia is apoptosis. $J$ Neurosci 15:1001-1011.

Oltvai ZN, Milliman CL, Korsmeyer SJ (1993) Bcl-2 heterodimerizes in vivo with a conserved homolog, bax, that accelerates programmed cell death. Cell 74:609 619.

Portera-Cailliau C, Hedreen JC, Price DL, Koliatsos VE (1995) Evidence for apoptotic cell death in Huntington's disease and excitotoxic animal models. J Neurosci 15:3775-3787.

Purdie CA, Harrison DJ, Peter A, Dobbie L, White S, Howie SE, Salter DM, Bird CC, Wyllie AH, Hooper ML, Clarke AR (1994) Tumour incidence, spectrum and ploidy in mice with a large deletion in the p53 gene. Oncogene 9:603-609.

Raff MC, Barres BA, Burne JF, Coles HS, Ishaizaki Y, Jacobson MD (1993) Programmed cell death and the control of cell survival: lessons from the nervous system. Science 262:695-700.

Represa A, Tremblay E, Ben-Ari Y (1987) Kainate binding sites in the hippocampal mossy fibers: localization and plasticity. Neuroscience 20:739-748.

Sakhi S, Bruce A, Sun N, Tocco G, Baudry M, Schreiber SS (1994) p53 induction is associated with neuronal damage in the central nervous system. Proc Natl Acad Sci USA 91:7525-7529.

Seto E, Usheva A, Zambetti GP, Momand J, Horikoshi N, Weinmann R, Levine AJ, Shenk T (1992) Wild-type p53 binds to the TATA-binding protein and represses transcription. Proc Natl $\Lambda$ cad Sci US $\Lambda$ 89:12028-12032.

Shaw P, Bovey R, Tardy S, Sahli R, Sordat B, Costa J (1992) Induction of apoptosis by wild-type $\mathrm{p} 53$ in a human colon tumor-derived cell line. Proc Natl Acad Sci USA 89:4495-4499.

Srivastava S, Zou ZQ, Pirollo K, Blattner W, Chang EH (1990) Germline transmission of a mutated $\mathrm{p} 53$ gene in a cancer-prone family with Li-Fraumeni syndrome. Nature 348:747-749.

Strasser A, Harris AW, Jacks T, Cory S (1994) DNA damage can induce apoptosis in proliferating lymphoid cells via p53-independent mechanisms inhibitable by bcl-2. Cell 79:329-339.

Symonds H, Krall L, Rernington L, Saenz-Robles M, Lowe S, Jacks T (1994) p53-dependent apoptosis suppresses tumor growth and progression in vivo. Cell 78:703-711.

Tasker RAR, Connell BJ, Strain SM (1991) Pharmacology of systemically administered domoic acid in mice. Can J Physiol Pharmacol 69:378-382.

Timme T, Thompson TC (1994) Rapid allelotype analysis of p53 knockout mice. Biotechniques 17:461-463.

Vaux DL, Cory S, Adams JM (1988) Bcl-2 promotes the survival of haemopoietic cells and cooperates with c-myc to immortalize pre-B cells. Nature 335:440-442.

Wood KA, Dipasquale B, Youle RJ (1993) In situ labeling of granule cells for apoptosis-associated DNA fragmentation reveals different mechanisms of cell loss in developing cerebellum. Neuron 11:621-632.

Yonish-Rouach E, Resnitzky D, Lotem J, Sachs L, Kimchi A, Oren M (1991) Wild-type p53 induces apoptosis of myeloid leukaemic cells that is inhibited by interleukin-6. Nature $352: 340-345$. 